\title{
IMPACT OF COLD STORAGE ON ANTIOXIDANTS ACTIVITY AND VITAMIN C IN MILK FLAVORED BY SUBTROPICAL FRUITS
}

\author{
MARWA IBRAHIM KHALIFA ${ }^{1}$ and ENAS AHMED NOSEER ${ }^{2}$ \\ ${ }^{1}$ Department of Food Hygiene, Faculty of Veterinary Medicine, Aswan University, 81528 Sahary City, Egypt \\ ${ }^{2}$ Department of Biochemistry, Faculty of Veterinary Medicine, Aswan University, 81528 Sahary City, Egypt
}

Received: 31 March 2019; Accepted: 15 April 2019

\begin{abstract}
However, Milk is considered the superior food. The addition of fruits into milk is to improve its functionality. In this study four subtropical fruits; Annona (Annona squamosal), Avocado (Persea Americana), Kiwi (Actinidia deliciosa), and Pomegranate (Punica granatum) were mixed with milk in concentrations of 20, 30, and 50\%. The concentration of total antioxidants (TAC) and vitamin C of samples were measured colorimetrically across 7 days of cold storage. The highest values of TAC were for annona and pomegranate flavored milk samples at day 0 (126.12 and $125.62 \mathrm{mM} / \mathrm{L})$ respectively, while by $7^{\text {th }}$ day all types of flavored milk samples losses its contents of antioxidants dramatically except the avocado milk sample which kept the highest contents $(118.76 \mathrm{mM} / \mathrm{L})$. The amount of vit. $\mathrm{C}$ is dropped across cold storage in an analogous manner of TAC. Sensory properties and over all acceptability of samples were at the side of annona and avocado flavored milk. Subtropical fruits must be added to milk under scientific control to avoid interaction with casein. The fruit flavored dairy should be consumed fresh to avoid destructive effect of cold storage on antioxidants.
\end{abstract}

Key words: flavored milk, antioxidants, vit C, ascorbic acid.

\section{INTRODUCTION}

Milk is considered the superior food for children as it contains all the nutrients necessary for human growth and health in balanced ratios. In addition to proteins, minerals and vitamins in milk, antioxidants play a vital role in protecting the body from free radicals and maintaining cell vitality. Milk is rich in both fat soluble antioxidants (conjugated linoleic acid, $\alpha$-tocopherol, $\beta$-carotene, vitamins A and D3, phospholipids) and water soluble antioxidants (proteins, peptides, minerals and trace elements.

Antioxidants are antitoxic protective substances dynamically overcome the destructive effects of the free radicals on human health as well as elongating shelf-life of foods by delaying its spoilage through inhibition of microbial and enzymatic activities which accelerate rancidity. The efficiency of antioxidants in human body cells is due to their capability to bind free radicals so preventing their destructive oxidant activity (Blasa et al., 2010).

There are various natural and synthetic antioxidants, with the natural ones being safer and demanded by

Corresponding author: Dr. Marwa Ibrahim Khalifa

E-mail address: mrwakhalifa@yahoo.com

Present address: Department of Food Hygiene, Faculty of Veterinary Medicine, Aswan University, 81528 Sahary City, Egypt consumers. Natural antioxidants (tocopherols, flavonoids \& phenolic acids) could be found besides milk in fruits, vegetables, grains and herbs.

Great antioxidant power was possessed by vitamin C in which it is easily converted from its reduced form (ascorbic acid) to its oxidized form (dehydroascorbic acid). Ascorbic acid or Vit $\mathrm{C}$ is rare in milk of all species except camel milk; (El-Hatmi et al., 2006) but fruits and vegetables supplied about $90 \%$ of a person's dietary requirement of vitamin C. (Salunkhe et al., 1991).

Vit. C attracts the attention of the research community and consumers as a nutrient with a broad biological activity and importance for human health. It supports the absorption of iron and the formation of collagen. Vit $\mathrm{C}$ is added to foods not only as a nutrient but also as an antioxidant. (Kirby et al., 1991).

Ascorbic acid intercepting in eliminating free radicals so, it minimizes damage to lipids, protein and nucleic acids (Zanini et al., 2018). Important functions in the body are performed by ascorbic acid like building and maintaining strong tissues especially, connective tissues (bones, cartilage, dentin, collagen, etc.), forming strong capillary walls for blood vessel, tissue building, resistance to infection, helps in the absorption of calcium, so it ensures the health of bones, haemoglobin synthesis 
by increase the bioavailability of iron, wound healing infections and fever recovery. It is important for tissue synthesis and naturally it is needed in growth stages of life. It helps in tying up free radicals so it is considered as strong reducing agents so it protects the body from their deleterious effects (Sumati et al., 2003). Although it has a great importance for metabolism due to its oxidation Vitamin $\mathrm{C}$ is a member of water soluble vitamins with molecular formula is $\mathrm{C} 6 \mathrm{H} 8 \mathrm{O} 6$ and its molar mass is $176.13 \mathrm{~g} / \mathrm{mol}$ and found in nature as isomer L (Blasa et al., 2010).

The core purpose for the consideration of fruits (organic natural additives) in milk is to increase its antioxidant activity and functionality. Taking in consideration the mood swings of children, their tastes may differ from milk. So many trails to improve and change milk taste are developed to suit all tastes and ensure the interest of children and adults to eat it. One of the best ways to improve the taste of milk is milk based beverages by inclusion of different fruits with different taste to provide a wide base of different tastes. The fortification of milk with fruiters is not only to improve the taste, but also improving its functionality, in that they provide all essential and non-essential amino acids but, are less acidic than plain fruit juices (Dalim et al., 2012). Also, added fruits found to have a significant effect on the milk content of antioxidants especially, fruits rich in antioxidants bioactive phytochemicals such as tropical annona, avocado, pomegranate, and kiwi. Therefore new ingredients in milk beverage industry will refine their nutritional quality.

This experiment was designed to detect the fluctuations in antioxidants and ascorbic acid levels and manner in milk as a result of mixing four subtropical fruits Annona (Annona squamosal), Avocado (Persea Americana), Kiwi (Actinidia deliciosa) Pomegranate (Punica granatum) as well as evaluation of the developed product sensory characters and consumer acceptability.

\section{MATERIALS AND METHODS}

\section{Raw materials}

\subsection{Milk}

UHT whole cow milk was used in this experiment. The production date was in the first week of the beginning of the self-life to minimize the probable damage in antioxidants activity.

\subsection{Sub-Tropical Fruits}

Four types of sub-tropical fruits (Annona, Avocado, Kiwi, and Pomegranate) were purchased from Aswan markets in late summer season in September 2018. The samples were fresh, healthy and intact.

\subsection{Fruit extract}

The extract was obtained by crushing $500 \mathrm{~g}$ of each type of fruits individually by a sterile mixer in a clean $1000 \mathrm{ml}$ capacity stainless container. Then filtrated twice through a sterilized muslin cloth to minimizing the amount of impurities and then collected in glass beakers.

\subsection{Flavored milk processing}

Different amounts of fruits extracts were inoculated into milk and mixed well to obtain concentrations of 20, 30, and 50\%. Neither preservatives nor sugars were used. Next Table pronounces the different formulae and abbreviations.

\begin{tabular}{cc}
\hline Code & Formulae \\
\hline Control & Plain UHT milk sample \\
\hline ANN20 & Annona milk juice 20\% \\
\hline ANN30 & Annona milk juice 30\% \\
\hline ANN50 & Annona milk juice $50 \%$ \\
\hline AVD20 & Avocado milk juice 20\% \\
\hline AVD30 & Avocado milk juice 30\% \\
\hline AVD50 & Avocado milk juice 50\% \\
\hline KW20 & Kiwi milk juice 20\% \\
\hline KW30 & Kiwi milk juice 30\% \\
\hline KW50 & Kiwi milk juice 50\% \\
\hline PMG20 & Pomegranate milk juice $20 \%$ \\
\hline PMG30 & Pomegranate milk juice $30 \%$ \\
\hline PMG50 & Pomegranate milk juice $50 \%$ \\
\hline
\end{tabular}

\section{Experiment design}

All formulae as well as control samples of plain whole UHT milk were kept in refrigerator $\left(4^{\circ} \mathrm{C}\right)$ and examined in days 0,5 , and 7 for antioxidants and Vit C contents.

\section{Antioxidant measurement}

Antioxidant activity was detected colorimetrical by Total Antioxidant Capacity kits (Biodiagnostic Lab) according to Koracevic and Koracevic (2001) using 3 reagents R1 Substrate, R2 Chromogen, R3 
Enzyme - Buffer. The blank as well as the sample were read against distilled water at $505 \mathrm{~nm}$.

\section{Ascorbic acid measurement}

Ascorbic acid level was detected colorimetrically by Ascorbic acid kits according to Harris, and Ray (1935) in which $0.1 \mathrm{ml}$ of sample was mixed with $0.5 \mathrm{ml}$ buffer and $1.0 \mathrm{ml} \mathrm{2,} \mathrm{6-dichlorophenol}$ indophenol (DCPIP) and measured against distilled water at wave length $520 \mathrm{~nm}$.

\section{Sensory evaluation}

\subsection{Physical properties}

The $\mathrm{pH}$ value of each formula was measured by $\mathrm{pH}$ meter (HANNA-pH 210, Germany).

\subsection{Rheological properties (Meilgaard et al.,} 2007)

The Taste, flavor, texture and over all acceptability of formulae were tested by 11 non experienced panelists ( 6 men and 5 women) aged between (20: 40 years). The panelists were the doctors and employee in Aswan University. They were asked to score the quality of coded dairy beverages samples on a 5 grades score card in which grade 1 means very bad, $3=$ fair and $5=$ very good.

\section{RESULTS}

Table 1: Total anti-oxidant capacity $(\mathrm{mM} / \mathrm{L})$ in flavored milk samples across 7 days of cold storage.

\begin{tabular}{cccc}
\hline & Day 0 \pm SE & Day 5 \pm SE & Day 7 \pm SE \\
\hline Control & $109.56 \pm 0.617$ & $114.22 \pm 0.779$ & $101.27 \pm 0.721^{*} * *$ \\
\hline ANN20 & $113.23 \pm 0.34$ & $102 \pm 0.09$ & $91.46 \pm 1.33 * * *$ \\
\hline ANN30 & $123.94 \pm 0.837$ & $116.82 \pm 0.671$ & $90.35 \pm 2.165^{* * *}$ \\
\hline ANN50 & $126.12 \pm 0.646$ & $121.31 \pm 0.326$ & $113.4 \pm 0.653$ \\
\hline AVD20 & $109.56 \pm 0.9238$ & $103.34 \pm 0.2935$ & $104.47 \pm 0.665 * * *$ \\
\hline AVD30 & $121.95 \pm 1.818$ & $122.87 \pm 0.876$ & $118.76 \pm 1.587$ \\
\hline AVD50 & $124.74 \pm 0.5484$ & $121.55 \pm 2.93$ & $114 \pm 0.88$ \\
\hline KW20 & $110.52 \pm 1.167$ & $101.32 \pm 0.587$ & $97.33 \pm 1.097 * * *$ \\
\hline KW30 & $116.08 \pm 0.635$ & $109.62 \pm 0.626$ & $103.55 \pm 1.1835$ \\
\hline KW50 & $120.39 \pm 1.2438$ & $109 \pm 1.1547$ & $100 \pm 1.1547 * * *$ \\
\hline PMG20 & $120.45 \pm 1.39$ & $86.21 \pm 1.1837$ & $66.84 \pm 0.733^{* * *}$ \\
\hline PMG30 & $121.74 \pm 1.01036$ & $93.31 \pm 0.7505$ & $72.74 \pm 1.010^{* * *}$ \\
\hline PMG50 & $125.62 \pm 0.682$ & $101.11 \pm 0.875$ & $87.75 \pm 1.181 * * *$
\end{tabular}

$* * * p<0.001$ indicate statistically significant differences compared to the control at day 0 .

Table 2: $\mathrm{pH}$ values of flavored milk samples across 7 days of cold storage.

\begin{tabular}{llll}
\hline & Day 0 \pm SE & Day $\mathbf{5} \pm \mathbf{S E}$ & Day 7 \pm SE \\
\hline Control & $6.58 \pm 0.06$ & $6.47 \pm 0.01$ & $6.52 \pm 0.01$ \\
\hline ANN20 & $6.2 \pm 0.05$ & $6.0 \pm 0.02$ & $5.5 \pm 0.06$ \\
\hline ANN30 & $6.3 \pm 0.05$ & $6.2 \pm 0.05$ & $6.0 \pm 0.03$ \\
\hline ANN50 & $6.3 \pm 0.11$ & $6.3 \pm 0.02$ & $6.3 \pm 0.01$ \\
\hline AVD20 & $6.2 \pm 0.01$ & $6.0 \pm 0.01$ & $6.0 \pm 0.01$ \\
\hline AVD30 & $6.2 \pm 0.02$ & $5.8 \pm 0.01$ & $5.9 \pm 0.12$ \\
\hline AVD50 & $6.27 \pm 0.03$ & $6.34 \pm 0.01$ & $6.27 \pm 0.01$ \\
\hline KW20 & $3.22 \pm 0.06$ & $3.00 \pm 0.03$ & $3.03 \pm 0.06$ \\
\hline KW30 & $3.4 \pm 0.057$ & $3.4 \pm 0.04$ & $2.9 \pm 0.06$ \\
\hline KW50 & $3.59 \pm 0.057$ & $3.2 \pm 0.057$ & $3.0 \pm 0.057$ \\
\hline PMG20 & $3.13 \pm 0.057$ & $3.00 \pm 0.01$ & $2.9 \pm 0.057$ \\
\hline PMG30 & $2.93 \pm 0.01$ & $2.5 \pm 0.057$ & $2.5 \pm 0.057$ \\
\hline PMG50 & $3.20 \pm 0.06$ & $2.4 \pm 0.057$ & $2.3 \pm 0.057$ \\
\hline
\end{tabular}




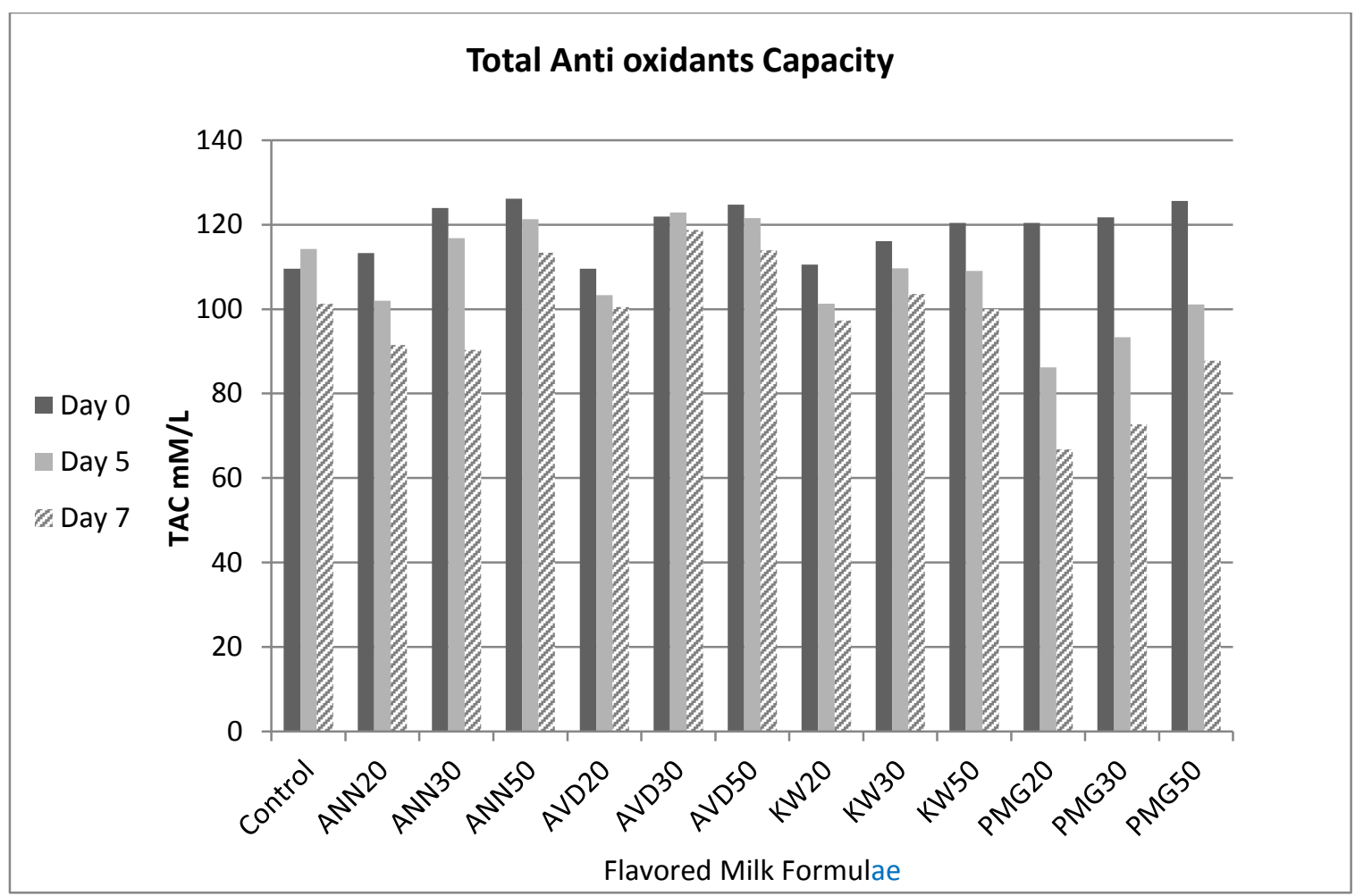

Fig. 1: Total Anti-oxidants capacity of flavored milk samples across 7 days of cold storage

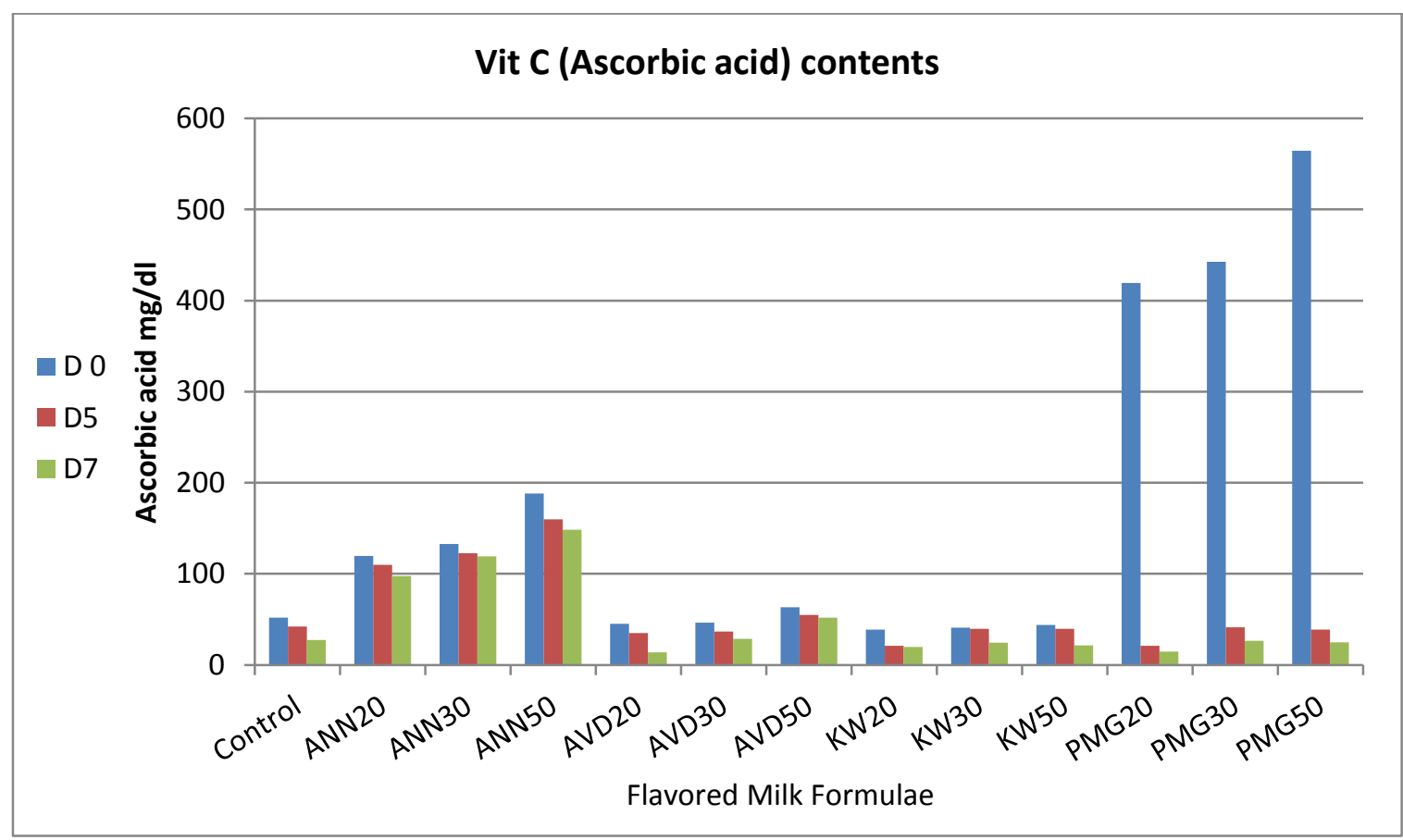

Fig. 2: Vitamin C (Ascorbic acid) contents in flavored milk samples across 7 days of cold storage 


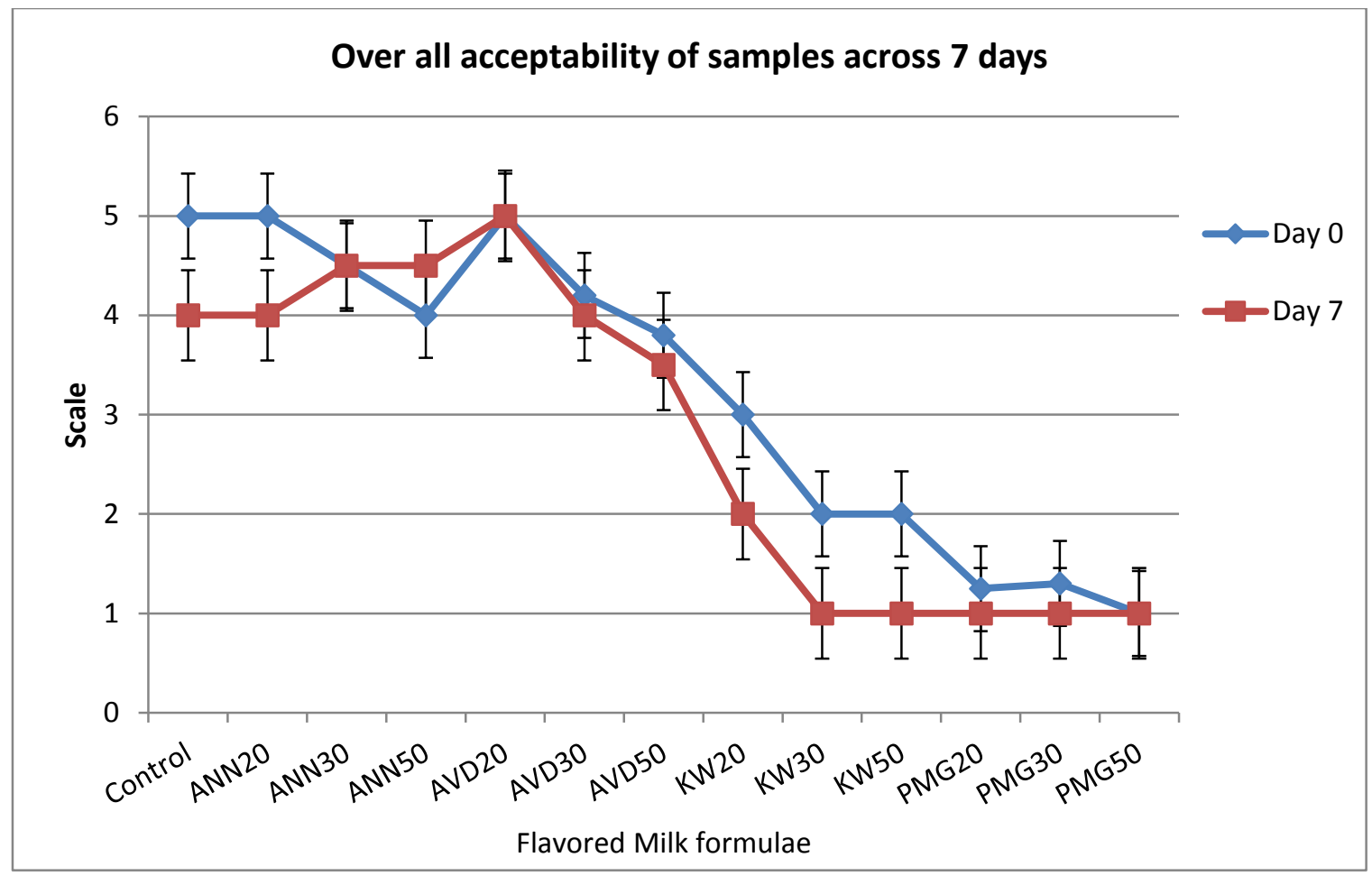

Fig. 3: Over all acceptability of flavored milk samples across 7 days of cold storage

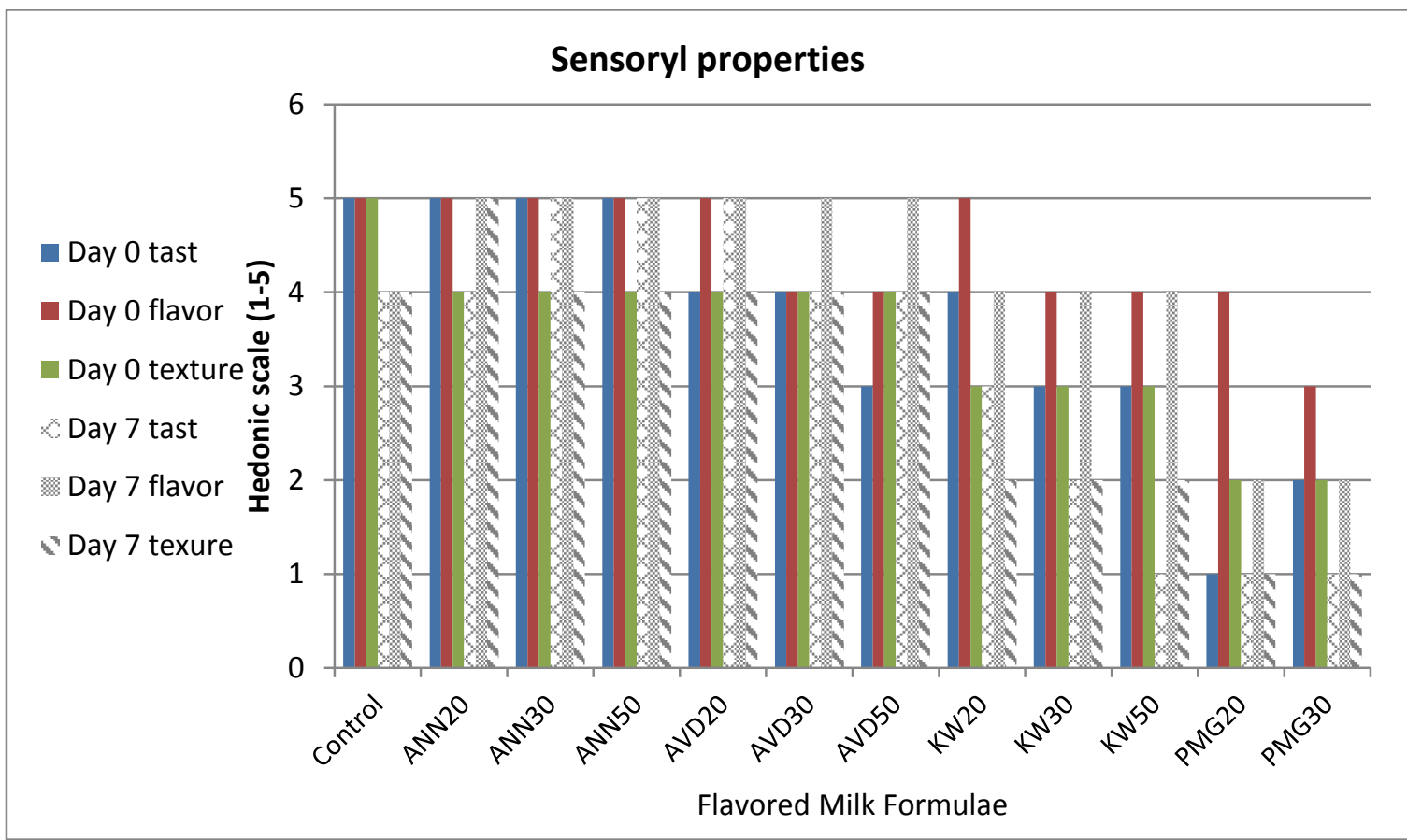

Fig. 4: Sensory properties of flavored milk samples across 7 days of cold storage

\section{DISCUSSION}

The purpose of milk inoculation with fruits is to make a superior functional food rich in natural antioxidants and fibers. Also milk is very rich in both lipophilic and hydrophilic antioxidants, but addition of fruits will multiply this capacity and improving taste and dietary fibers content.

\section{Antioxidant levels in milk beverages}

The significance of antioxidant activity in the dairy beverages is conveying both the shelf life and human body cell protection against oxidative damage.

Table (1) and fig. 1 showed that the Total antioxidant capacity (TAC) of the control sample 
(UHT skim cow milk) in day zero of the experiment was $109.56 \mathrm{mM} / \mathrm{L}$. Higher values (456) to (356) $\mu \mathrm{mol} / \mathrm{L}$ were measured by oxygen radical absorbance capacity (ORAC) assay in (UHT) cow milk, by Chen et al. (2003) and Zulueta et al. (2009a). This could be attributed to many variables, such as methodology of extraction, reduced fat contents which carry a significant part of lipophilic antioxidants and variances in methodology. The type of plant also may be responsible for the concentrations of bioactive compounds beside other factors as genetic factors, maturity stage, environmental. (Ddriozola-Serrano et al., 2008; Albuquerque et al., 2016).

Total antioxidant capacity in all milk samples fortified with the fruits was higher than the plain milk in day 0 . Specially the concentration of $50 \%$ annona (ANN50) and pomegranate (PMG50) in which the antioxidant capacity of pomegranate juice was shown to be higher due to the free radicals scavenging activity, and iron reducing capacity of the juice (Gil et al., 2000).

By the $5^{\text {th }}$ day all samples showed decline in its content of TAC except avocado beverages which kept TAC balanced between day 0 and 7 (121.95 and118.76) for beverage of $30 \%$ concentration and 124.74: 114 for $50 \%$ concentration, respectively. This is may be due to that avocado is rich in lipophilic antioxidants components such as carotenoids, unsaturated fatty acids including oleic, linoleic, palmitoleic acid which with long storage are subjected easily to oxidative stress. (Ding et al., 2007).

Moreover, Gómez et al. (2014) recorded high TAC of avocado parts in a dose-dependent manner. High redox power and oxygen chelation of edible plant extracts was due to its high contents of phenols and antioxidants Adedapo et al. (2008). The kiwifruit had significantly higher radical scavenging activities at the start of fruit development, but it decreased as the fruit matured (Ramesh et al., 2015). This explains the drop of TAC in Kiwi flavored milk samples in this study. Also, a desirable change that occur during ripening of pomegranate in which the fruit losses its acidity due to reduce the levels of phenolic compounds (Fawole and Opara, 2013) may be the cause of losing large value of TAC in pomegranate milk samples by cold storage.

In this study it was obvious that for all flavored milk types the total antioxidant capacity increased by the increasing of fruits concentration up to $30 \%$ and then no significant effect were observed. El-Said et al. (2014) recorded similar observation in stirred yogurt fortified with pomegranate peel extract.

The recorded decline in TAC in most examined dairy beverages may be due to interactions between phenolic compounds of fruits and lipids, carbohydrates and proteins of milk. Numerous previous studies found that milk diminished the antioxidants capacity of beverages by about $30 \%$. This impact is thought to happen in light of the fact that the milk casein has affinity power for antioxidants, lessening their capacity to battle unsafe free radicals. (Bourassa et al., 2013, Serafini et al., 2009. Jakobek 2015).

\section{Ascorbic acid contents}

Ascorbic acid (Vit C) is the major hydrophilic antioxidant. It is raising the human body immunity, vessels elasticity, reducing circulation disturbances and bleeding due to capillary damage and therefore in food ascorbic acid protects from or at least delay spoilage and rancidity.

It is well known that bovine milk is not a rich source of Ascorbic acid; on the other hand fresh fruits are recommended as vit $\mathrm{C}$ suppliers.

Fig. 2 declared that Ascorbic acid (AA) in control sample dropped significantly between day 0 and day 7 of cold storage from 51.9 to $27.3 \mathrm{mg} / \mathrm{dl}$, respectively. This is may be due to that Vit $\mathrm{C}$ is hydrophilic in nature and is very sensitive to dryness resulted from long storage. Similar consequences were recorded by Silva et al. (2018) in infants and children foods.

In all samples of fruits beverages the vit $\mathrm{C}$ degradation after 5 days of cold storage at $5 \mathrm{C}^{\circ}$ was noticeable. In Samples of pomegranate beverages PMG 20 was sharply dropped from 442.8 to 26.7 $\mathrm{mg} / \mathrm{dl}$ across 7 days of storage. Quirós et al. (2009) found similar pattern of vit $\mathrm{C}$ degradation in cold stored foods. Galani et al. (2017) recorded significant decrease in vit $\mathrm{C}$ contents in fruit foods by cold storage. While, milk samples with avocado and Annona Vit $\mathrm{C}$ contents degraded gradually. The wide changes in the degradation levels in different beverages formulae could be recognized to many causes, such as fruit nature, milk components interaction with fruit, AA contents and nature in each fruit, and concentration of fruits in beverage. Also vitamin binding proteins in milk could react with Vit $\mathrm{C}$ and developing of complexes (Claeys et al., 2013). Moreover, other vitamins (B1, B2 and $\mathrm{B} 12$ ) and metal (Fe, $\mathrm{Cu}$ and $\mathrm{Zn}$ ) contained in milk are able to interact with vitamin $\mathrm{C}$, thus increasing its degradation rate.

\section{Determination of $\mathbf{p H}$}

The normal cow milk $\mathrm{pH}$ is slightly acidic ranged between 4.4 and 4.8. Table (3) showed the plain UHT milk sample has $4.58 \mathrm{pH}$ value and remain constant across 5 and 7 days of cold storage with non-significant drop (4.44 and 4.52), respectively. Although kiwi and pomegranate have more acidic reactions. By the day 5 the $\mathrm{pH}$ of formulae PMG2, 
PMG30 and PMG50 were sharply dropped to reach $3.00,2.5,2.4$, respectively and showing the lowest $\mathrm{pH}$ (2.3) among all formulae at day 7. Zulueta et al. b (2013) recorded significant decrease in $\mathrm{pH}$ of acidic fruit milk beverages by cold storage at day 7 . This fall in $\mathrm{pH}$ value of milk is due to acidity of pomegranate peel. So, pomegranate is not proper to inoculated into milk as a beverage of storage period due to sever drop of acidity which leads to watery appearance of milk. But pomegranate may add to milk for immediate consumption only.

On the other hand, annona and avocado fruit beverages showed a less acidic pH. Annona beverages have a $\mathrm{pH}$ ranged between 6.0 and 6.3 and the drop of value was very narrow from day 0 to day 7. Hassan et al. (2015) recorded parallel results in $\mathrm{pH}$ of fruit dairy beverages during refrigerated storage.

Concerning, avocado milk formulae, the $\mathrm{pH}$ values ranged from 5.8 to 6.58 . The highest concentration formulae AVD50 the $\mathrm{pH}$ was 6.85 and kept balanced in cold storage with minor decreases.

\section{Sensory properties of dairy beverages}

The sensory evaluation was presented in Fig. $(3,4)$. In respect of beverage flavor, panelists evaluated all samples as good to very good. But according to texture, pomegranate samples (PMG10, PMG20, PMG30) were classified as very bad due to weakness of texture and separation of liquid, while, annona beverage (ANN20, ANN30, ANN50) and avocado (AVD20, ADV30) were classified as very good for texture due to good viscosity, while AVD50 was classified as bad to texture this may be due to AVD50 contain large amount of avocado pulp $50 \%$ which is responsible for thick creamy texture. (Concha-Meyer et al., 2016).

In respect to overall acceptability (OAA) in Fig. (3) Samples of ANN20, ANN30, ANN50, AVD20 were scoring between good and very good. Kiwi samples coded KW20, KW30, KW50 were moderately acceptable (3, 2, 2 respectively) while, PMG samples were recorded as very bad and recommended to used freshly to avoid beverage separation.

According apparent descriptions the samples of ANN have white color like creamy milk and sweetly taste, AVD samples were greenish in color and slightly bitter in taste. KW samples were yellowish white and have banana like taste with kiwi seeds. PMG were pale brown in color and pomegranate taste.

\section{CONCLUSIONS}

Mixing milk it with sub-tropical fruits must be under scientific control not industrial design to avoid interaction between casein and plant components, and to achieve complete benefits. Also the long storage of dairy beverages over 5 days is not recommended to avoid degradation of antioxidants and Vit $\mathrm{C}$ content.

\section{REFERENCES}

Adedapo, A.A.; Jimoh, F.O.; Koduru, S.; Afolayan, A.J. and Masika, P.J. (2008): Antibacterial and antioxidant properties of the methanol extracts of the leaves and stems of Calpurnia aurea. BMC Complement. Altern. Med., 8: 53-59.

Albuquerque, T.G.; Santos, F.; Sanches-Silva, A.; Dliveira, M.B.; Bento, A.C. and Costa, H.S. (2016): Nutritional and phytochemical composition of Annona cherimolain fruits and by-products: potential health benefits. Food Chemistry, 193: 187-195.

Blasa, M.; Gennari, L.; Angelino, D. and Ninfali, P. (2010): Fruit and Vegetable Antioxidants in Health. ( $3^{\text {rd }}$ Ed). Bioactive food in promoting health, p.: 37-58. R. Wasten \& V. Breedy. New York.

Bourassa, P.; Côté, R.; Hutchandani, S.; Samson, G. and Tajmir-Riahi, H.A. (2013): The effect of milk alpha-casein on the antioxidant activity of tea polyphenols. J Photochem Photobiol B. 5; 128: 43-9.

Chen, J.; Lindmark-Månsson, H.; Gorton, L. and Akesson, B. (2003): Antioxidant capacity of bovine milk as assayed by spectrophotometric and amperometric methods. Int. Dairy J., 13: 927-935.

Claeys, W.L.; Cardoen, S.; Daube, G.; De Block, J.; Dewettinck, K. and Dierick, K. (2013): Raw or heated cow milk consumption: review of risks and benefits. Food Control, 31, 251262.

Concha-Meyer, A.A.; D'Ignoti, V.; Saez, B.; Diaz, R.I. and Torres, C.A. (2016): Effect of storage on the physico-chemical and antioxidant properties of strawberry and kiwi leathers. J. Food Sci., 81: 569-577.

Dalim, M.; Khaskheli, M.H.; Baloch, M.; Soomro, Aijaz Hussain; Khaskheli, Gul, S.; Mangsi, A. and Barham, Ghulam. (2012): Production and comparison of banana and chikoo flavoured milk-based beverages. Pakistan J. of Nutrition, 11.

Ddriozola-Serrano, O.; Soliva-Fortuny, $R$. and Martín-Belloso, D. (2008): Effect of minimal processing on bioactive compounds and color attributes of fresh-cut tomatoes. LWT - Food Science and Technology, 41 (2):217-226.

Ding, H.; Chin, Y.W.; Kinghorn, A.D. and D'Ambrosio, S.M. (2007): Chemopreventive characteristics of avocado fruit. Seminars in Cancer Biology, 17(5): 386-394. 
El-Hatmi, H.; Khorchani, T. and Attia, H. (2006): Characterizationand composition of camel's (Camelus dromedarius) colostrum and milk. Microbiol. Hyg. Alim., 18: 13-17.

El-Said, M.; Haggag, H.F.; Fakhr El-Din, H.M.; Gad, A.S. and Farahat, A.M. (2014): Antioxidant activities and physical properties of stirred yoghurt fortified with pomegranate peel extracts. Annals of Agricultural Science, 59 (2): 207- 212.

Fawole, O.A. and Opara, U.L. (2013): Developmental changes in maturity indices of pomegranate fruit. Scientia Horticulturae, 159: $152-161$.

Jakobek, L. (2015): Interactions of polyphenols with carbohydrates, lipids and proteins. Food Chemistry, 175: 556-567.

Galani, J.; Mankad, P.; Shah, A.; Patel, N.; Rajeshkumar, R.; Acharya, C. and Talati, J. (2017): Storage of Fruits and Vegetables in Refrigerator Increases their Phenolic Acids but Decreases the Total Phenolics, Anthocyanins and vitamin $\mathrm{C}$ with subsequent loss of their antioxidant capacity. Antioxidants, 6(3): 59-66.

Gómez, F.S.; Sánchez, S.P.; Iradi, M.G.G.; Azman, N.A.M. and Almajano, M.P. (2014): Avocado seeds: extraction optimization and possible use as antioxidant in food. Antioxidants 3 (2): 439-454.

Gil, M.I.; Tomás-Barberán, F.A.; Hess-Pierce, B.; Holcroft, D.M. and Kader, A.A. (2000): Antioxidant activity of pomegranate juice and its relationship with phenolic composition and processing. J. Agric. Food Chem., 48: 4581-4589.

Hassan, M.; Dar, B.N.; Rather, S.A.; Akhter, R. and Huda, A.B. (2015): Physico chemical, sensory and microbial characteristics of fruit flavoured milk based beverages during refrigerated storage. Adv. Biomed. Pharma., 2(1): 32-39.

Harris, L.J. and Ray, S.N. (1935): Calorimetric method for detection of ascorbic acid. Lancet, $1,71,462$.

Kirby, C.J.; White, C.J.; Rigby, N.; Coxon, D.T. and Law, B.A. (1991): stabilization of ascorbic acid by microencapsulation in liposomes. Inter. J. Food Sci. Tech., 26: 437-449.

Koracevic, D. and Koracevic, G. (2001): Calorimetric method for detection of total antioxidants. J. Clin. Pathol., 54: 356-361.
Meilgaard, M.C.; Civille, G.V. and Carr, B.T. (2007): Sensory evaluation techniques. $4^{\text {th }}$ ed. CRC Press, Boca Raton, FL.

Quirós A.; Fernández-Arias, M. and LópezHernández, J. (2009): A screening method for the determination of ascorbic acid in fruit juices and soft drinks. Food Chemistry 116: 509-512.

Ramesh, S.P.; Vandana, A.K.; Sandeep, A.; Sharma, A.K.; Virendra, K. and Sanjeev, A. (2015): Physicochemical and antioxidant properties of kiwifruit as a function of cultivar and fruit harvested month. Braz. Arch. Biol. Technol., 58 (2): 262-271.

Salunkhe, D.K.; Bolin, H.R. and Reddy, N.R. (1991): Storage processing and nutritional quality of fruits and vegetables, 2:323.

Serafini, M.; Testa, M.F.; Villaño, D.; Pecorari, M.; Wieren, K.V.; Azzini, E.; Brambilla, A. and Maiani, G. (2009): Antioxidant activity of blueberry fruit is impaired by association with milk. Free radical biology \& medicine, 46 6, 769-74.

Silva, M.; Albuquerque, T.; Beatriz, M. and Costa, H. (2018): Vitamin C evaluation in foods for infants and young children by a rapid and accurate analytical method. Food Chemistry, 267: 83- 90.

Sumati, R. and Rajagopal, M. (2003): Fundamentals of foods and nutrition. Fourth Edition.Published K. K. Gupta. Ne Age international (p) LTD.P.135.

Zanini, D.J.; Henrique, S.M.; Aguiar, O.E.; Roberta, M.M.; Setsusko, K.E. and Resendem, M.R. (2018): Spectrophotometric analysis of vitamin $\mathrm{C}$ in different matrices utilizing potassium permanganate. European Int. J. Sci. Techno., ISSN: 2304-9693.

Zulueta, A.; Maurizi, A.; Frígola, A.; Esteve, M.J.; Cole, R. and Burini, G. (2009) (a): Antioxidant capacity of cow milk, whey and deproteinized milk. Int. Dairy. J., 19: 380385.

Zulueta, A.; Barba, F.J.; Esteve, M.J. and Frígola, A. (2013) (b): Changes in quality and nutritional parameters during refrigerated storage of an orange Juice-Milk beverage treated by equivalent thermal and nonthermal processes for mild pasteurization. Food Bioprocess Technol., 6: 2018-2030. 


\section{تأثير التبريد على مضادات الأكسدة وفيتامين سي في اللبن المطعم بالفواكه المدارية مروة إبراهيم خليفة ، إبياس أحد نصبير}

E-mail: mrwakhalifa@yahoo.com Assiut University web-site: www.aun.edu.eg

يعتبر اللبن أكمل الأغذية قيمة وأكثرها شعبية، ويتم اضافة الفاكهة له لزيادة محتو اه من الالياف ومضادات الاكسدة. وقد تم في هذه الرها

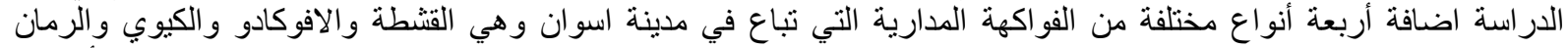

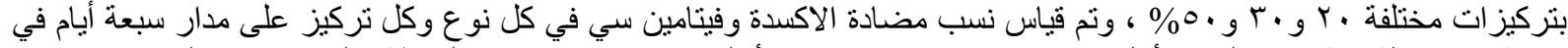

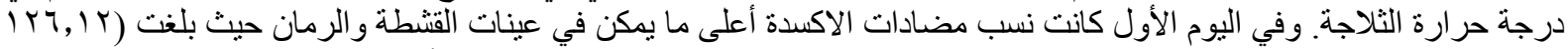

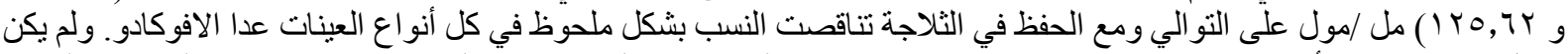

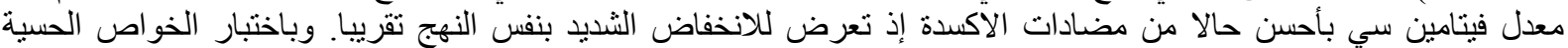

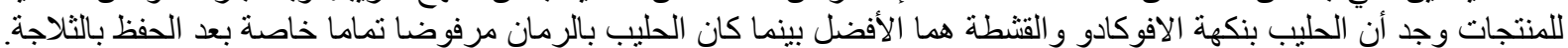

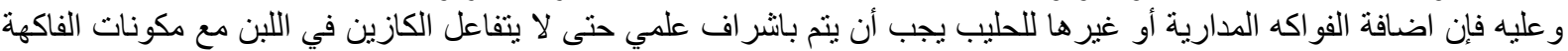

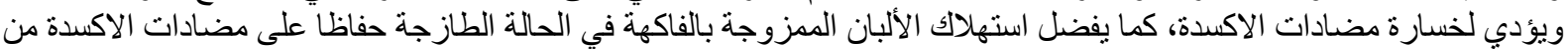
تأثثير البرودة المدمر. 